
Revue
de l'histoire des religions
Revue de l'histoire des religions
$1 \mid 2012$
Judaïsme / christianisme : syncrétismes, antinomies, dissonances

\title{
Starting sacrifice in the beyond Flavian innovations in the concept of priesthood and their repercussions in the treatise "To the Hebrews"
}

Sacrifier dans l'au-delà : les innovations flaviennes du concept de sacerdoce et leurs répercussions sur l' "Épitre aux Hébreux»

Jörg Rüpke

\section{(2) OpenEdition}

Journals

Electronic version

URL: http://journals.openedition.org/rhr/7831

DOI: 10.4000/rhr.7831

ISSN: 2105-2573

Publisher

Armand Colin

Printed version

Date of publication: 1 March 2012

Number of pages: 5-30

ISSN: 0035-1423

\section{Electronic reference}

Jörg Rüpke, «Starting sacrifice in the beyond Flavian innovations in the concept of priesthood and their repercussions in the treatise "To the Hebrews" », Revue de I'histoire des religions [Online], 1 | 2012, Online since 01 March 2015, connection on 01 May 2019. URL : http://journals.openedition.org/ rhr/7831; DOl : 10.4000/rhr.7831 


\section{Starting sacrifice in the beyond Flavian innovations in the concept of priesthood and their repercussions in the treatise "To the Hebrews"}

The paper accepts the thesis of a Roman origin of "Hebrews" around the end of the first century AD. This implies an educated audience raised in late Neronian or Flavian times and informed by Roman culture as expressed in public buildings, images and even-if we think about a Jewish family background-rituals. The text is thus analyzed in terms of contemporary urban culture and religion. Special attention is given to the priestly roles discussed. These are compared to the prominent role of pontifex maximus of the Roman emperors and to the developments of major public priesthoods during the second half of the first century $A D$.

\section{Sacrifier dans l'au-delà : les innovations flaviennes du concept de sacerdoce et leurs répercussions sur l' «Épître aux Hébreux»}

Cette étude accepte la thèse d'une origine romaine de l' "Épitre aux Hébreux » à la fin du premier siècle de l'ère chrétienne. Cela suppose un auditoire instruit, apparu la fin de l'époque néronienne ou flavienne et rompu à la culture romaine, telle qu'elle s'exprime dans les édifices publics, les images et même - si l'on songe à un contexte familial juifles rituels. Le texte est ainsi analysé en termes de culture et de religion urbaines contemporaines. Une attention spéciale est accordée aux rôles des prêtres, rôles qui sont comparés à celui, central, de pontifex maximus, assuré par les empereurs romains, et aux développements des principaux sacerdoces publics dans la seconde moitié du premier siècle de notre ère. 


\section{1/ READING CANONICAL TEXTS}

One of the most important developments of the history of religion in the imperial Roman period is the substitution of sacrificial religious practices by reading practices, as argued by Guy Stroumsa in his book on the end of sacrifice. ${ }^{1}$ Christian cult, which had developed as other ritual towards miniaturization and towards replacing sacrifice by memory of sacrifice ${ }^{2}$ could only thus function by the possibility to refer to sacrifices in texts. This is not to argue for any previous unseen sacrificial interpretation on such a basis. There is enough of sacrifice in the Bible to render void such a claim. But there is much more going on in many texts than replacement, spiritualisation, or memory. Across religious boundaries-that appear to have been much less strong and clear as usually supposed-texts engaged with contemporary religious practices, cross-fertilizing different traditions and thus leading to surprising innovations.

By accepting the communis opinio of a Roman origin of the tractate or sermon to the "Hebrews" at the end of the first or beginning of the second century $\mathrm{AD},{ }^{3}$ this paper tries to argue such an innovation and engagement with contemporary religious practices across textual traditions for a text from the inner canon of Christian writings with all the consequences in reception for the centuries to come by such a privileged status. The dating implies an educated Jewish audience raised in late Neronian or Flavian times and informed by Roman culture as expressed in public buildings, images and rituals. Without disregarding the intertextual relationship to Scripture, "Hebrews" is thus analyzed in terms of contemporary urban religion.

1. Guy Stroumsa, La fin du sacrifice. Les mutations religieuses de l'Antiquité tardive. Paris, 2005 (Collection Collège de France).

2. Cf. Guy Stroumsa, Barbarian Philosophy: The Religious Revolution of Early Christianity. WUNT 112. Tübingen 1999, 40-41.

3. See below. Craig R. Koester, Hebrews: A New Translation with Introduction and Commentary, in: The Anchor Bible, vol. 36. New York 2001, 50 opts for a date between 60 and 90; Harold W. Attridge, The Epistle to the Hebrews. A Commentary. Philadelphia 1989, 9: 60 to 100.

4. See below, and in particular Gabriella Gelardini, "Hebrews, an Ancient Synagogue Homily for Tisha be-Av: Its Function, its Basis, its Theological Interpretation." In: ead. (ed.), Hebrews: Contemporary Methods - New Insights. Biblical Interpretations Series 75. Leiden 2005, 107-127. 
Even if the sacrificial metaphor ( $\left.\pi \rho 0 \sigma \varphi \varepsilon \varepsilon^{\prime} \varepsilon \mathrm{v} \nu \delta \hat{\omega} \rho \alpha, \theta v \sigma^{\prime} \alpha \mathrm{l}\right)$ is very important for the sermon, my special attention is given to the priestly roles involved in the transcendental sacrificial scenario. These are compared to the prominent role of pontifex maximus of the Roman emperors and to the developments of major public priesthoods towards the end of the first century AD. Such a look promises a deepened understanding of the cultural setting of the text and the interaction of its audience with the institutional setting of Rome, of which any audience in the Roman Empire would be part in institutional and in cultural terms. This is hardly late antiquity, but it is an analysis of one of the fundamental texts responsible for the shape of late antique Christianities. Despite this history of reception, I regard the genesis of the text as much a date of the history of Roman Judaism as Christianity.

\section{2/ Determining Contexts}

Obviously, New Testament as well as classical scholars like me are struck by the massive presence of sacerdotal semantics, a Jesuology (to remain careful) centring around the figure of a heavenly high priest in the anonymous text called "Ad Hebraeos". The results of 'Quellenforschung' could be summed up like this: Using the pentateuchal description of priestly service in "Exodus" and "Numeri", especially focusing on atonement rituals, and Psalm 110 (109 LXX), ${ }^{5}$ perhaps barely traceable elements of Qumranic Melchizedek traditions, ${ }^{6}$ early Jesus-as-intercessor motives ${ }^{7}$ and first century spiritualisations of priesthood and cult as witnessed by Philo, ${ }^{8}$ the unknown author of the text elaborated all that into

5. See John M. Scholer, Proleptic Priests. Priesthood in the Epistle to the Hebrews. Journal for the Study of the New Testament Supplement Series 49. Sheffield 1991, 83.

6. Andrew Lincoln, Hebrews: A Guide. London/New York 2006, 45; rather optimistic: Eric Farrel Mason, "You Are a Priest forever": second Temple Jewish Messianism and the Priestly Christology of the Epistle to the Hebrews. Leiden 2008, 203.

7. William R.G. Loader, Sohn und Hohepriester: eine traditionsgeschichtliche Untersuchung zur Christologie des Hebräerbriefes. Wissenschaftliche Monographien zum Alten und Neuen Testament, Bd. 53. Neukirchen-Vluyn 1981, 100.

8. Sceptical: Koester 2001, 59-60. Lincoln Douglas Hurst, The Epistle to the Hebrews: its background and thought. Cambridge 1990, 133, stresses apart from 
a fully-fledged theory of the elevated Crucified as high priest and son. Originality is certain in comparison to the traditions used. The intellectual and scriptural network thus established offers neither an explanation nor even a motif.

With only a few obvious clues present in the text, hypotheses about its setting and the presuppositions for any interpretation move in a hermeneutic circle. Our placing of the text influences our reconstruction of possible associations of contemporary readers, or better: hearers. Given the few clues of the text regarding place and time of its production or addressees, I have to proceed on hypotheses. Domitian time is an easy, though-I repeat-hypothetical choice, ${ }^{9}$ and I extend this period to include the early Trajanic period, too. The most reliable evidence for a terminus ante quem is the quotation or rather direct borrowing by 1 Clem 36.2-6, most probably dated between 90 and $120 \mathrm{AD} .{ }^{10}$ Some of my arguments, I have to stress, depend on this decision in dating. Rome or Italy are the most probable among the few feeble possibilities as far as the place is concerned; in the final line (13.24) the senders are identified as people "who are from Italy" (apò tês Italías). ${ }^{11}$ My argument does not depend on this choice, but it is helped very much.

Roman religion has not featured prominently among New Testament scholars. Following a proud nineteenth-century distinction, happily elaborated by classical scholars of the twentieth century, exegetics from the Religionsgeschichtliche Schule onwards have restricted their interest to what slowly ceases to be called "oriental religions" 12 and Greek philosophy. The history-of-religion approach in recent commentaries on "Hebrews" checks for instance

the Septuagint (in particular Ps 8) and the Old Testament traditions of Acta 7 the Pauline theology and contemporary Jewish apocalyptic (4 Ezra, 1 Enoch), but the priestly figure "remains a riddle".

9. See Ellen Bradshaw Aitken, "Portraying the Temple in Stone and Text: The Arch of Titus and the Epistle to the Hebrews." In: Gelardini 2005, 133-6, for an early Domitian date by supposing that "Hebrews" directly reacted to the imagery of Titus as displayed in the Arch of Titus.

10. Attridge 1989, 7

11. See also Attridge 1989, 10 pointing to the reception by the Roman 1 Clemens.

12. See the contributions in Corinne Bonnet, Jörg Rüpke, Paolo Scarpi (edd.), Religions orientales - culti misterici: Neue Perspektiven - nouvelles perspectives - prospettive nuove PawB 16, Stuttgart 2006; Mediterranea 1 (2008); Corinne Bonnet, Jörg Rüpke (edd.), Les religions orientales dans les mondes grec et romain $=$ Die orientalischen Religionen in der griechischen und römischen Welt 
for Hellenic or Hellenistic-Jewish thought, Gnostic influences or Qumran parallels, and stops there. Yet Rome was the oppressing reality of the imperial Mediterranean, even if mitigated by distance or Greek language. Koester in his helpful Anchor bible commentary points several times to the "Greco-Roman" environment, but in fact his examples are Greek only in an anachronistic way and blandly Roman by the end of the first century AD. ${ }^{13}$ Given the slight chance that the text derives from the city of Rome or heavily romanized urban centres, we have to pay as much attention to local Roman traditions as many do for Alexandrian or Jerusalem ones. Here I fully agree with approaches that stress the importance of the Roman, i.e. Titus' triumph ${ }^{14}$ or the general religious role of the emperors, even if I am going to offer an alternative account.

Roman context and the dating have two corollaries, the question of persecution and the destruction of the temple. From an historical point of view, the evidence for any persecution of Christians under Domitian is feeble. ${ }^{15}$ For Rome, Xiphilinos' excerpt of the third-century historian Cassius Dio (the sources of Dio's negative version of Domitian are difficult to identify $)^{16}$ points to religious arguments employing the concept of ta ton Ioudaion ethe in the persecution of members of the senatorial class and possibly beyond. This, however, relates to the very last year of Domitius' reign. I do not wish to enter into the discussion of John's 'Apocalypsis'. Its dating is itself subject to the problem of circularity. ${ }^{17}$ But even admitting a Domitian date does not attest to more than some local conflicts in Asia Minor. Despite the negative portrait of the emperor in the senatorial and later Christian historiography and by Pliny, ${ }^{18}$ it is most probable that the

= Trivium: Revue franco-allemande de sciences humaines et sociales/Deutschfranzösische Zeitschrift für Geistes- und Sozialwissenschaften 4, Paris 2009.

13. Koester 2001, 78 f.

14. E.g. Aitken $2005,142 \mathrm{ff}$.

15. Joachim Molthagen, "Die Lage der Christen im römischen Reich nach dem 1. Petrusbrief: Zum Problem einer domitianischen Verfolgung." Historia 44, 1995, 422-458.

16. See Christiana Urner, Kaiser Domitian im Urteil antiker literarischer Quellen und moderner Forschung. Diss. Augsburg 1993, 49 f.

17. Cf. Ulrike Riemer, Das Tier auf dem Kaiserthron? Eine Untersuchung zur Offenbarung des Johannes als historischer Quelle. Beiträge zur Altertumskunde 114. Stuttgart 1998, 7-11.

18. For the latter and his underrated reception see Urner 1993, 319. 
enthusiastic image conveyed by the poets Martial (who, however, never had direct access to the emperor $)^{19}$ and Statius was more representative of popular feeling than the formers' accusations, even if the poets' readership has to be surmised in the ranks of an upper class rather than the larger populace directly addressed by Domitian with the help of games and military spectacles rather than the employment of poets. ${ }^{20}$

Vespasianus' and Titus' destruction of the temple of Jerusalem are of larger importance. The Romans' ending of centralized Jewish sacrificial ritual and the factual disappearance of the priesthood offered an important instigation to reflect about this area of religious practice and to develop it into a resource of powerful symbols and imagination. Evidently, that would have been an important precondition for the engagement with related developments in Roman religion. A Jewish audience would have been used-and opposed-to emperor worship from Hellenistic times onwards. The Flavian innovations and intensifications in this area ${ }^{21}$ would have been noticed, even if not welcomed in the manner reflected in, for example, Statius' poems. ${ }^{22}$ Yet the image of the emperor was shaped by many a role; being god-like was just one element in it. Others, political, patronage, military, cultural roles were fundamental, even through the lenses, the perspective offered by emperor worship. Religious roles, and in particular sacerdotal roles, were among them. ${ }^{23}$ People were able to react differently to changes in these roles - this is another hypothesis that I need and hope to make plausible.

19. Jens Leberl, Domitian und die Dichter: Poesie als Medium der Herrschaftsdarstellung. Hypomnemata 154. Göttingen 2004, 343.

20. The latter is stressed by Leberl 2004, 344 f.; Ruurd R. Nauta, Poetry for Patrons: Literary Communication in the Age of Domitian. Mnemosyne suppl. 206. Leiden 2002, 327-335, likewise underlines the fact, that poetic honouring of the emperor need not imply personal imperial patronage; A.J. Boyle, "Introduction: Reading Flavian Rome.” In: id.; J. W. Dominik (edd.), Flavian Rome: Culture, Image, Text. Leiden: Brill, 2003, 41, speaks of the new theatricality of the Flavian and in particular Domitianic period.

21. See Manfred Clauss, Kaiser und Gott: Herrscherkult im römischen Reich. Stuttgart 1999, 112-132.

22. E.g. Franz Sauter, Der römische Kaiserkult bei Martial und Statius. Tübinger Beiträge zur Altertumswissenschaft 21 Stuttgart 1934.

23. Richard Gordon, "The Veil of Power: emperors, sacrificers and benefactors." In: Mary Beard, John North (edd.), Pagan Priests: Religion and Power in the Ancient World. London 1990, 201-231. 
My reference to the image of Domitian has already paved the way for my thesis. In taking up traditions from the Tenakh, the author of "Hebrews" with brilliant rhetoric paints the image of heavenly Jesus-or more precisely Iesus Dei filius, to translate the Greek formulation at the start of the central part of the sermon (4.14: Iêsoûn tòn uíon toû theoû) as a priest who is in concurrence with the supreme priest embodied by the earthly emperor-and, of course, winning. The emperor cannot challenge transcendent sacrifice and priestly honours.

My demonstration of this thesis will be developed in three steps. First, I try to make plausible that the priestly role of the second and third Flavian emperors was a threat to the eagerness of the Jewish group following Jesus. Second, I try to make plausible that "Hebrews" sacerdotology tackled this problem. And thirdly I am going to explain a few corollaries of my thesis.

\section{3/ Changing concepts of PRiesthood}

As was usual for princes and indeed many nobles, Titus and Domitianus became members of public priesthoods at a comparatively young age. Titus was co-opted into, as it was said, "all colleges" in AD 71, that would imply membership of the pontiffs, augurs, Quindecimviri sacris faciundis, responsible for the Sibyline Books, and the Septemviri Epulones as a minimum. ${ }^{24}$ Perhaps at the same time, certainly by the year 73 Domitian was co-opted into the same colleges and among the Arval brethren. ${ }^{25}$ Such a membership demanded occasional presence; the formal dress was identical to the toga praetexta worn by magistrates in office. Visibility of the priestly role, hence, was restricted to a few ritual events.

From Augustus onwards, the acclamation as emperor had led to an additional honour, the election to the office of pontifex maximus, ${ }^{26}$

24. Rüpke, Fasti sacerdotum: A Prosopography of Pagan, Jewish, and Christian Religious Officials in the City of Rome, 300 BC to AD 499. Biographies of Christian Officials by Anne Glock. Trsl. by David Richardson. Oxford 2008, [in the following FS], Nr. 1017; CIL $6.31294=$ ILS 258; 6.40453.

25. FS Nr. 1470; CIL 9.4955 = ILS 267 and CIL 3.12218; NS 1899.64 attests membership among the XVviri already for AD 72.

26. See Ruth Stepper, "Der Kaiser als Priester: Schwerpunkte und Reichweite seines oberpontifikalen Handelns.” In: Hubert Cancik, Konrad Hitzl (edd.), Die 
the only of the many religious offices that became an element of full imperial titulature. Formally, this was just the head of the large pontifical college, ${ }^{27}$ but the office entailed certain prerogatives towards other priests and was opened to plebeians and made a subject of a specific sort of popular election from the third century $\mathrm{BC}$ onwards. ${ }^{28}$ Caesar entered into this office four years before his first consulship, Augustus did without it for the first quarter of a century of his reign. Even if it became afterwards a standard component of the extended form of imperial nomenclature, it is extremely difficult to relate specific actions to this office. Nearly everything we associate with religious policy of the emperors had nothing to do with the office of pontifex maximus, transliterated to Greek as pontiphex maximos or translated as archiereus or archiereus megistos. This holds true down to the reinterpretation of the office by the emperor Julian in the $360 \mathrm{~s}^{29}$

There were, however, exceptions. Titus was the first, as Suetonius in his biography, written by the $120 \mathrm{~s},{ }^{30}$ relates in an astonishing phrase. Probably suffering from bad press, on entering the supreme pontificate, probably a few months after his accession to the throne, he made a declaration that he would keep his hands pure and promised that he would rather die himself than killing anybody else:

Pontificatum maximum ideo se professus accipere ut puras seruaret manus, fidem praestitit, nec auctor posthac cuiusquam necis nec conscius, quamuis interdum ulciscendi causa non deesset, sed periturum se potius quam perditurum adiurans (Suet. Tit. 9.1).

"Having declared that he would accept the office of pontifex maximus for the purpose of keeping his hands unstained, he was true to his promise; for after that he neither caused nor connived at the death of any man, although he sometimes had no lack of reasons for taking

Praxis der Herrscherverehrung in Rom und seinen Provinzen. Tübingen 2003, 157-187; ead., Augustus et sacerdos: Untersuchungen zum römischen Kaiser als Priester. PawB 9. Stuttgart 2003, 35-39 and 45; Françoise van Haeperen, Le collège pontifical ( $3^{e}$ s. a. C. $-4^{e} s$. p. C. ) : contribution à l'étude de la religion publique romaine. Bruxelles 2002, $153 \mathrm{f}$.

27. van Haeperen 2002, 94-96.

28. Rüpke, Fasti sacerdotum: Die Mitglieder der Priesterschaften und das sakrale Funktionspersonal römischer, griechischer, orientalischer und jüdischchristlicher Kulte in der Stadt Rom von 300 v. Chr. bis 499 n. Chr.. PawB 12/1-3. Stuttgart 2005, $1623 \mathrm{f}$.

29. Rüpke 2008, 57-66.

30. And after his release from imperial service: Andrik Abramenko, "Zeitkritik bei Sueton: Zur Datierung der Vitae Caesarum.” Hermes 122 (1994), 80-94. 
vengeance; but he swore that he would rather be killed than kill" (trsl. J.C. Rolfe, Loeb Library).

Magistrates had to swear an oath (iusiurandum) on the laws within five days of entering office; there is no other evidence for elected priests having to perform the like. The connection of priestly offices with ethics is not a new one in Roman culture, Livy in his history of Rome relates an event of the year 209 BC, when an unwilling noble, a Gaius Valerius Flaccus, was forced into the office of flamen fialis by the pontifex maximus - and changed his way of life as a consequence. ${ }^{31}$ Yet, purus, "clean" is occasionally used of ritual purity of instruments or animals (Paul. Fest. p. 248 M; Varro, rust. 2.1.20 and Plin. nat. 8.206), rarely-and only in association with the Vestal virgins-as a priestly quality (Ov. am. 3.8.23 purus ... sacerdos in a metaphorical way); Vesta and the rites connected with her-and hence her priestesses, the Vestal virgins-deal with purgamina and hence the concept of purus (Ov. fast. 4.731-4; 6.225-234 in Augustan times). Given this background, Titus' initiative should be judged innovative, not simply fitting to the office. ${ }^{32}$

Domitian, following his brother in 81, stressed the office of pontifex maximus in a similar manner. Like earlier emperors, his office was announced on coins $(C R E B M \quad 2,300 \mathrm{ff}$. 7a ff. $=R I C 2$, Domitian 11-23) as on many inscriptions. Evidence of a particular stress on the pontificate is provided by Suetonius' detailed account of his multiple prosecutions of Vestals, a task intimately connected with the office of pontifex maximus: ${ }^{33}$

Incesta Vestalium uirginum, a patre quoque suo et fratre neglecta, uarie ac seuere coercuit, priora capitali supplicio, posteriora more ueteri ... (Suet. Domit. 8.3-4; corroborated by Dio 67.3.3 f.).

"He punished the cases of sexual misbehaviour of the Vestal virgins, that had been neglected by his father and brother, in different and severe ways, first by capital punishment, later in the old manner [of burying alive] ..."

The first case must be related to around $83 \mathrm{AD}$, that is, already early in his reign; the second might belong to around $89 .{ }^{34}$ It had

31. Livy 27.8.4-10; Val. Max. 6.9.3; FS Nr. 3393.

32. Thus Stepper 2003a, 147.

33. Stressed by Stepper 2003a, 148-153.

34. As argued by Gsell, see Brian W. Jones, The Emperor Domitian. London $1992,218$. 
wide repercussions that transcended historiography; a reference to his personal role in the investigation as an explorator might be found in Statius' Silvae. ${ }^{35}$

Another incidence that would be most easily related to the office of the supreme pontiff concerned the dealing with a member of the pontifical college, the flamen dialis. Witness is born by the contemporary Plutarch's "Roman Questions" (50):

"Why did the priest of Jupiter (flamen dialis) resign his office if his wife died, as Ateius has recorded? Is it because ... Or is it because the wife assists her husband in the rites, so that many of them cannot be performed without the wife's presence, and for a man who has lost his wife to marry again immediately is neither possible perhaps nor otherwise seemly? Wherefore it was formerly illegal for the flamen to divorce his wife; and it is still, as it seems, illegal, but in my day Domitian once permitted it on petition. The priests were present at that ceremony of divorce and performed many horrible, strange, and gloomy rites."

Further evidence, overlooked so far, is given by the inscription of an altar dedicated to Volcanus. The lex of the altar presents itself as the reinvigoration of an annual vote instituted at the time of the Neronian fire at Rome. Here, the wording of the inscription clearly differentiates between the emperor Domitian, who dedicated the altar, the annually changing official who has to perform the rite, and the pontifex maximus Domitian, who constituted the sacral regulation $(C I L 6,826=6,30837 \mathrm{a}-\mathrm{c}=I L S 4914=A E 2001,182)$ :

Haec area intra hanc/definitionem cipporum/clausa veribus et ara quae / est inferius dedicata est ab /[[[Imp(eratore) Caesare Domitiano Aug(usto)]]] / [[[Germanico]]] ex voto suscepto / quod diu erat neglectum nec / redditum incendiorum / arcendorum causa / quando urbs per novem dies / arsit Neronianis temporibus / hac lege dedicata est ne cui / liceat intra hos terminos / aedificium exstruere manere / negotiari arborem ponere / aliudve quid serere / et ut praetor cui haec regio / sorti obvenerit litaturum se sciat / aliusve quis magistratus / Volcanalibus X K(alendas) Septembres / omnibus annis vitulo robio / et verre // Haec area intra hancce / definitionem cipporum / clausa veribus et ara quae / est inferius dedicata est ab /Imp(eratore) Caesare Domitiano Aug(usto) / Germanico ex voto suscepto / quod diu erat neglectum nec / redditum incendiorum / arcendorum causa / quando urbs per novem dies / arsit Neronianis temporibus / hac lege dedicata est ne cui / liceat intra hos terminos / aedificium exstruere manere /

35. Philip Hardie, Statius and the Silvae. Poets, patrons and epideixis in the Graeco-Roman world. Liverpool 1983, 203 n. 68; Jones 1992, 101 on Stat. silv. 1.1.36. 
nego $<$ t>iari arborem ponere / aliudve quid serere / et ut praetor cui haec regio / sorti obvenerit sacrum faciat / aliusve quis magistratus / Volcanalibus X K(alendas) Septembres / omnibus annis vitulo robeo / et verre $<f>a c($ tis) precationibus / infra script $<i s>$ aedi[3] K(alendas) Sept(embres) / ianist [3] / [3] dari [3]quaes [3] / quod imp(erator) Caesar Domitianus / Aug(ustus) Germanicus pont(ifex) max(imus) / constituit $Q[---] /$ fieri // ex voto suscepto / quod diu erat neglectum nec / redditum incendiorum / arcendorum causa / quando urbs per novem dies / arsit Neronianis temporibus / hac lege dedicata est ne cui / liceat intra hos terminos / aedificium exstruere manere / negotiari arborem ponere / aliudve quid serere / et ut praetor cui haec regio / sorti obvenerit litaturum se sciat / aliusve quis magistratus / Volcanalibus X K(alendas) Septembres / omnibus annis vitulo robio / et verre.

It is the supreme pontiff who sets the regulations (constituit).

Other activities cannot be related to the office of pontifex maximus, ${ }^{36}$ but attest to a degree of religious activities that was unknown to earlier emperors since Augustus. Suetonius mentions the founding of a new priestly college related to the cult of Minerva $(4.4)^{37}$ and a new dress for the sodales Flaviales and the flamen dialis. $^{38}$ The founding of the new Capitolian agon is to be related to the year 86, in 88 Domitian had secular games organized, again using coins to broadcast his religious activities; the series with different ritual details is truly exceptional. ${ }^{39}$

It is not only the number of newly founded games or temples ${ }^{40}$ Domitian has to be credited with the rebuilding of the Capitol, the so-called Forum Transitorium, the completion of the domus aurea and the Flavian amphitheatre ("Colosseum") 41 -but it is the visibility of religious offices that must be seen as characteristic of his reign and the time immediately preceding. ${ }^{42}$ Not only did he

36. $C f$. Stepper 2003a, $154 \mathrm{f}$., who makes further suggestions.

37. For Minerva see Jean-Louis Girard, "Domitien et Minerve: une prédilection impériale." ANRW II.17,1 (1981), 233-245.

38. Ibid.

39. CREBM 2, no. 419-438; rightly stressed by Harry O. Maier.

40. Suet. Domit. 5, see Jones 1992, 102-6 for details and further evidence.

41. See David Fredrick, "Architecture and Surveillance in Flavian Rome." In: A. J. Boyle, J. W. Dominik (edd.), Flavian Rome: Culture, Image, Text. Leiden 2003, 205-9 on the characteristics of Domitian's architecture. Emmanuelle Rosso, "La diffusion de l'idéologie flavienne dans les provinces occidentales de l'Empire: le décor sculpté des monuments publics", in: M. Navarro Caballero and J.-M. Roddaz (eds.), La transmission de l'idéologie impériale dans l'Occident romain. Ausonius Études 13. Bordeaux 2006, 247-271, discusses the consequences of this strategy, to create a specifically Flavian Rome, in the provinces.

42. I am grateful to Ellen Bradshaw Aitken for pointing this out to me. 
survive the civil war of 69 in the guise of an Isiac priest (1.2), ${ }^{43}$ but he also published an edict prohibiting the sacrifice of cattle during the absence of Vespasianus (9.1): Whatever the exact content and circumstances, Suetonius' anecdote points to a very particular public image of Domitian, giving him a specific religious aura as a religious actor, not only as a recipient of ruler cult.

In analyzing the religion of the Flavian period, historical research has not stressed the emperors' priestly offices, but the veneration of the emperor, imperial cult. It is especially the work of Duncan Fishwick that has given clear chronological shape to the development of this type of cult during the empire, based on literary as well as archaeological and in particular inscriptional evidence. For the ruler cult, in an empire-wide perspective, "the Flavian era is ... the most significant period since its origins under Augustus", now including the living emperor from the start. ${ }^{44}$ Without a noble and urban background, the new dynasty stressed ruler cult as a vehicle for legitimacy and authority (ibid., 96). This included Titus' new sodales Flaviales and temple of divus Vespasianus as his brother's inclusion of deified Titus into these projects. ${ }^{45}$

I do not wish to even sketch Flavian ruler cult, but rather highlight a few motifs that might be relevant for our understanding of "Hebrews". Stress is laid on the presence, the closeness of the divine emperor in comparison to other gods: humanos propior Iove digerit actus says Statius, "he who nearer than Jove directs the doings of mankind" (Stat. Silv. 5.1.38), ${ }^{46}$ or genium domini praesentis (V. 74). The dominus et deus (Suet. Dom. 13.2) is a deus prasens (see Stat. Silv. 1.1.62: forma dei praesens). His throne of

43. See Francesco Paolo Arata, "Un 'sacellum' d'età imperiale all'interno del Museo Capitolino.” BCAR 98 (1997), 129-162 for the location.

44. Duncan Fishwick, The imperial cult in the Latin west: Studies in the ruler cult of the western provinces of the Roman Empire. III: 1. EPRO 145. Leiden, 2002, 95; Kenneth Scott, The Imperial Cult Under the Flavians. Stuttgart 1936 is still a mine for details; see Maria Kantiréa, Les dieux et les dieux Augustes: Le culte impérial en Grèce sous les Julio-claudiens et les Flaviens. Etudes épigraphiques et archéologiques. Meletemata 50. Athens 2007, 84 for a new routine of dedications in Greece.

45. See Clauss 1999, $120 \mathrm{f}$; for the location see the suggestion of Daniela Candilio, "Indagini archeologiche nell' aula ottagona delle Terme di Diocleziano." NS 1/2 1 (1990/91), 165-183.

46. Trsl. J.H. Mozley. Publius Papinius Statius: Silvae. Loeb Classical Library 206. Cambridge: Harvard University Press, 1982. 
gold and ivory is put up among the gods (Plin. Paneg. 52.1), that is, his gold statue is set up in the temple (Stat. Silv. 5.1.189-191). A radiant crown (Plin. ibid.) is included. Domitian is son and father of the gods: salve, magnorum proles genitorque deorum, "Hail, offspring and sire of mighty deities" (Stat. Silv. 1.1.74). ${ }^{47}$

In the context of imperial Judaeo-Christian history, "ruler cult" tends to immediately produce images of images being venerated by sacrifice, undue veneration of human beings putting off any reasonable man. This is very much a provincial perspective, the presence of the emperor being reduced to statues. Statues played an important role at Rome, too, but they served to enforce a presence of an emperor personally visible on many occasions, to the few as to the populace. In their poems, Domitian's contemporaries Statius and Martial ${ }^{48}$-flatterers, maybe, but highly valued poets at the same time-paint the image of a popular emperor-maybe charismatic more by office than personality-, construing his imperial authority by use of religious media, too. Religious language and devotion is a genuine means of answering to this, the top of rhetorical flattery and genuine admiration, grateful and awesome at the same time. Honouring somebody above average meant to get to the inventory of honouring the gods, to replace bronze by gold statues, to move the statue inside a temple, to compare actions not with other human ones but with those of the gods. Glamour and eccentricity, visibility and arrogance might have put off members of the old elites and some intellectuals - criticism and executions are attested and elite historiographers like Tacitus indulged in such opposition and make us love their narratives and insinuations. But why should researchers living in today's society doubt such phenomena's attractiveness to a majority of contemporaries?

In such a perspective, imperial cult should not be seen in isolation. For the emperors, receiving cult and performing cult are necessary complements. Piety and religious activities indicated the

47. Trsl. Mozley.

48. See K. Coleman, "The Emperor Domitian and Literature." ANRW II.32,5 (1986), 3087-3115; Hubert Cancik, "Größe und Kolossalität als religiöse und aesthetische Kategorien: Versuch einer Begriffsbestimmung am Beispiel von Statius, Silve I 1: Ecus maximus Domitiani imperatoris." Visible Religion 7(1990), 51-68; repr. id., Verse und Sachen: Kulturwissenschaftliche Interpretationen römischer Dichtung, ed. Richard Faber, Barbara von Reibnitz, Würzburg: Königshausen \& Neumann, 2003, 224-248, esp. 232-6. 
importance of the religious field and invited its being treated by others. Filling religious roles was, as I have shown in the beginning, part of the stock of public political roles, even before the imperial age. The competition with precursors and possible co-runners led to modification, intensification and innovation. Augustus filled and stressed a wide range of religious roles, not all related to priestly functions: The important role of the emperor as performer of sacrifice was not usually dependent on a sacerdotal office. Titus' and Domitian's stress on the supreme pontificate must be seen as an innovation.

Whereas the other priestly colleges stressed equality-and hence forced the emperor to communicate by letters and reduce their presence to rare occasions as secular games (this holds true for the Quindecimviri sacris faciundis) - the pontifex maximus could act on his own on many occasions. A century of principate had made it the prerogative of the emperor and the only religious office visible in standard titulature. Severe problems remained: the visibility of the role was, as I have shown, restricted and had to be realized by actions both cruel and spectacular such as punishing Vestals.

The potential of the office-in contrast to being augur, pontiff, vir epulonum, fetial or sodalis, now an office without rivals-is demonstrated by a contemporary in a text addressing a successor of Domitian's; it is demonstrated in Pliny's panegyric on Trajan (AD 98-117), a speech held on the $1^{\text {st }}$ September 100 and published in a considerably enlarged form probably in the year following. Very few passages name the pontificate of the emperor (who is gratefully addressed for the transferral of the consulate), but the three of them are highly significant. ${ }^{49}$ Stressing the modesty of the emperor, ${ }^{50}$ Pliny employs the titulature to contrast the sitting consul with the emperor standing before him:

Stupeo, patres conscripti, necdumque satis aut oculis meis aut auribus credo, atque identidem me an audierim, an viderim interrogo. Imperator ergo et Caesar et augustus pontifex maximus stetit ante gremium consulis, seditque consul principe ante se stante et sedit inturbatus interritus et tamquam ita fieri soleret (Plin. Paneg. 64.2).

"I am surprised, senators, and neither believe my eyes or ears, and

49. For references to Trajan's divine status see D. S. Levene, "God and Man in the Classical Latin Panegyric." Proceedings of the Cambridge Philological Society 43 (1997), 66-103, esp. 78-82.

50. An important strategy in this as in earlier panegyrics, see ibid., 78 . 
again and again ask myself, whether I see or hear: For the Imperator and Caesar and the august supreme pontiff stand before the lap of the consul, and the consul sat while the princeps was standing before him and he sat untroubled and without fear and as if that was usual."

Many modern editions introduce a further "and" $(e t)$ between Augustus and pontifex maximus, but that would spoil the triple expression (as employed in 88.7 and 10). In other passages Pliny uses the adjectival force of augustus, he plays with the comparative augustior $(8.3 ; 52.1 ; 60.2 ; 71.4)$, hence an adjectival use should not be excluded here. It is this conjunction that expresses the climactic structure, giving the highest possible qualification of the princeps, "the first man", a religious ring, implicated as much in augustus as in pontifex. It is the priestly office that removes the emperor from the world of ordinary man more than anything else.

Equally important is that the reflection about the fittingness of Trajan's wife is conceptualized with reference to this priesthood:

Tibi uxor in decus et gloriam cedit. Quid enim illa sanctius, quid antiquius? Nonne si pontifici maximo eligenda sit coniunx, aut hanc aut similem ... elegerit? (83.5)

"Your wife brings you decorum and fame. What could be more blameless than her, what more having the virtues of old? If the supreme pontiff had to choose a wife, he would have elected her or a similar."

The religious ring of the context is visible in the term sanctius and even antiquius. Pliny implies that among all offices held by Traian, it is the supreme pontificate that involves the highest standards and hence is suitable to judge whether the wife is matching the qualities of the emperor.

These observations are confirmed in the final prayer to Iuppiter (c. 94). Referring to the adoption by Nerva (AD 96-98), Pliny formulates:

Tu voce imperatoris [id est Nervae] quid sentires locutus, filium illi nobis parentem tibi pontificem maximum elegisti (94.4).

"You have spoken with the voice of Nerva, what you thought; you have made his son a father for us and a supreme pontiff for yourself."

It is in the role of the supreme pontiff that Trajan entertains the direct contact to the polity's highest god. Avoiding functional political terms, it is the concept of being a son that describes the most intimate relationship to the predecessor, the concept of fatherhood - of course referring to the official title of pater patriae- 
that describes the most intimate relationship with the people, and the concept of the supreme pontiff, that describes the most intimate relationship with the god of somebody, who equals the gods already in his ability to answer prayers. ${ }^{51}$ On the basis of our knowledge of the Flavian period and their strategies of legitimacy sketched above, Pliny, writing at the very beginning of a new reign, might have modified, but basically must have based his speech on patterns established before. $^{52}$

\section{4/ Sacerdotology in "Hebrews"}

My attempt to read "Hebrews" as a reaction to the Flavian period-as we are used to read Pliny - takes its justification not only from the originality of the canonical sermon's priestly images, but from a peculiar observation. The development of the high priest theologumenon in "Hebrews" starts with an expression that is quite unusual (4.14):

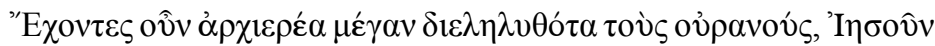

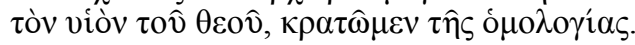

"Therefore, since we have a great high priest who has passed through the heavens, Jesus the son of God, let us hold fast the confession."

Archiereus megas (Hebr 4.14) is not the title of the high priest used in the Septuaginta, the Greek version used elsewhere, ${ }^{53}$ that normally uses hiereus megas. Biblically used in 1 Macc 13.42 only, the phrase must be judged exceptional. ${ }^{54}$ As archiereus megistos is the standard expression for pontifex maximus-archiereus being used for local or provincial chief priests-a reference or better: a semantic signal asking for reflection on one of the most commonly known offices of the time must be inferred.

Such a reference would not be exceptional. Without laying stress on these passages, Koester has pointed to a number of passages

51. Levene 1997, 81.

52. Cf. Nauta 2002, 412-4 for topoi dealing with honorific speeches and poetry.

53. Koester 2001, 59.

54. E.g. Philip Edgcumbe Hughes, A commentary on the Epistle to the Hebrews. Michigan 1977, 169; Erich Gräßer, An die Hebräer, in Hughes Brox et al. (ed.): Evangelisch-katholischer Kommentar zum Neuen Testament, Bd. XVII/ 2. Zürich/ Braunschweig/Neukirchen 1990, 245. 
that imply differences to contemporary Roman practices or claim comparable status for Jesus. In fact, the sermon starts with titulature, onoma (1.4). ${ }^{55}$ It stresses the divine transferral of the office ${ }^{56}$ instead of the self-arrogation of the office (5.4 f.): ${ }^{57}$

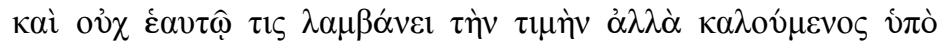

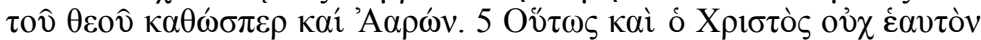

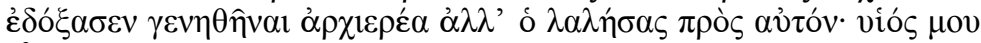

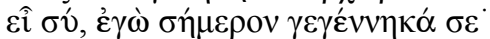

"And one does not take the honor for himself, but is called by God, just as Aaron was. (5) So also Christ did not glorify himself so as to become high priest; rather it was he who said to him, You are my Son, I have begotten you today."

The uniqueness of the priestly office (7.11-19) could be contrasted with the plurality of Roman priesthoods (359) even held by the same emperor. Jesus makes new ways metaphorically as Domitian (especially in his last years) did literally $(10.20 ; 448)$. The heavenly sanctuary (tes skenes tes alethines, 8.2 ) is not man-made as the many urban temples (381). Perhaps even the-now I quote the Latin of the Vulgata-testamenti sponsor (7.22) could have a contemporary reference, as Suetonius transmitted Domitian's excessive demand for heredities in the context of his dealing with the Jews (Domit. 12.2). In the posthumous panegyric on the successor Trajan, Pliny refers to Domitian's avaritious and illegal dealing with others' testaments and contrasts the new Trajanic practice of respecting testaments (39-40). There is no Tenakh parallel for this latter phrase, as there is no oath-taking of the high priest in Exodus 28:58 The image of Jesus' priesthood is informed by contemporary institutions rather than by Scripture.

To develop a Jesuology of a heavenly priestly office replies to a recent political development, but concentrates on an aspect that would allow to frame the derogative comparison of the emperor-a potentially capital crime - in a strictly religious language. Focussing on the supreme pontificate of the emperor (recently stressed by

55. Koester 2001, 187; see Alain Martin, La titulature épigraphique de Domitien. Beiträge zur klassischen Philologie 181. Frankfurt am Main 1987 for Domitian's.

56. Matthias Rissi, Die Theologie des Hebräerbriefs: Ihre Verankerung in der Situation des Verfassers und seiner Leser. WUNT 41. Tübingen 1987, 52.

57. Koester 2001, 297.

58. Frederick Fyvie Bruce (ed.), The Epistle to the Hebrews. Revised Edition. Michigan 1990, 170. 
Vespasian's sons) does not only potentially reinterpret the Flavian destruction of the Jerusalem temple perhaps commemorated on the occasion of the homily (see below). This recent religious development in the city of Rome enabled the author of "Hebrews" to counter the attractiveness of the towering figure of the emperor on like terms. Priestly offices are compared. Given the complex composition of Domitian's (like later emperors') earthly and divine status, the argument grew complex and led to inconsistencies: The shifting between the earthly and the heavenly high priest was necessary to locate the argument within the Jewish tradition and to establish the high priest of the Pentateuch as the competing office. The fact that already the dim tradition of Melchisedek combined a priestly office with kingship may have invited the choice of it. At the same time this office, temporarily obliterated by Titus, had to be transgressed towards an incomparable heavenly office, held by the son of god, Iesus dei filius.

"Son of god" was valid for Domitian, too, and thus the author of the sermon specified $(1,6)$ :

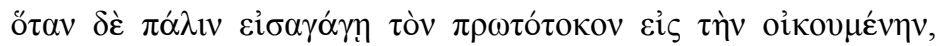

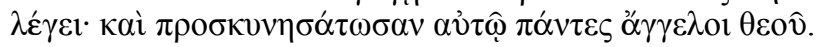

"And when, again, he brings the firstborn into the world, he says, And let all the angels of God bow down before him."

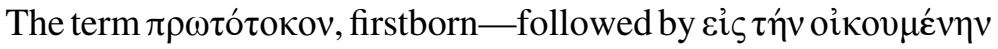
(1.6) — does not only take up a known Christological title as used in 1 Col 1.18 or Rom $8.29,{ }^{59}$ but gives it a political ring. Domitian, by all means, was born in second place, only.

Confronting Jesus and the living emperor (of course for reasons of criminal law never referred to explicitly or even by name), however, need not and could not lead to a concurrence in megalomania. Rhetorically, just the opposite could be useful. .0 "Hebrews" stresses the humanity, the compassion of the son (e.g. 2.11-18) even in relationship to the office (4.15):

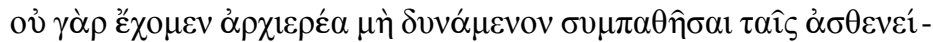

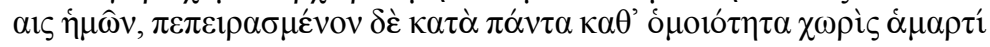
$\alpha \varsigma$.

59. Cf. the hesitation of August Strobel, Der Brief an die Hebräer. Das Neue Testament Deutsch 9/2. 4. rev. ed. (1975). Göttingen 1991, 23.

60. For the rhetorical qualities of "Hebrews" see Hermut Löhr, "Reflections of Rhetorical Terminology in Hebrews." In: Gelardini 2005, 199-210 2005, 201 and $209 \mathrm{f}$. 
"For we do not have a high priest who is unable to sympathize with our weakness, but one who has been tested in every respect, in these same ways, without sin."

This again strikingly compares with the strategy of Pliny early in his speech:

Nusquam ut deo, nusquam ut numini blandiamur: non enim de tyranno sed de cive, non de domino sed de parente loquimur. unum ille se ex nobis... (2.3 f.).

"Never shall we flatter him as a god, never as a divinity. We do not speak of a tyrant, but of a citizen, not of a lord, but of a father. 'I am one of you' (did he say)..."

Again, this is a reference to Domitian's having himself addressed as dominus et deus (see above), but again it is implying expectations of an audience that might have been shared by "Hebrews" addressees: Legitimacy by sonship is important, but a follower of Jesus cannot hope to have the crucified win a concurrence in mere divinity. To the contrary, compassion and closeness was an argument. ${ }^{61}$ The role of the highest priest must have been a standard set by Domitian - and failed by the same to the judgment of at least the upper class. Otherwise, Pliny would not have dwelled on it in crucial passages of his speech. "Hebrews" followed the same route in opening the eyes of the audience to the standing of their own idol (and I quote and recontextualise Koester): "Rather than rejecting the importance of a high priest, "Hebrews" declares that in Christ we have a great priest (10:21), thereby giving the Christian community a distinctive focus for its identity", ${ }^{62}$ distinctive, as I should like to add, since competitive.

It might be noted that the earliest possible testimony of reception, 1 Clemens, uses the high priest title of Jesus Christ in the phrase archiereus kai prostates, in Latin: Pontifex et patronus $(36.1 ; 61.3)$, associating military structures in the following chapter (37). In using the title of high priest, Clemens Romanus obviously associated the combination of contemporary roles realized by the emperor.

61. $C f$. the list of qualities collected by Donald A. Hagner, Encountering the Book of Hebrews: An Exposition. Grand Rapids: Baker, 2002, 104, and Patrick Gray, "Brotherly Love and the High Priest Christology of Hebrews." Journal of Biblical Literature 122 (2003), 335-351.

62. Koester 2001, 449. 


\section{5/ Conclusion}

My reasoning had to remain hypothetical throughout. It is not a result, but a more fully elaborated version of my thesis that is going to conclude my arguments. If Gelardini is right in assuming a Tisha be-Av dating for the homily of "Hebrews", ${ }^{63}$ the commemoration of the destruction of the second temple could bring out differences between the group addressed and its Roman environment-Roman certainly in a political, perhaps even in a geographical sense. The group constituted an audience that was in danger of losing in eagerness, if it has been rightly observed that "Hebrews" addresses "a certain weariness in pursuing the Christian goal" 64 rather than in fear under the impact of persecution; even apostasy was considered a real danger by the author. ${ }^{65}$ The rhetorical strategy aimed not at radical dichotomy and incompatibility, but at concurrence on equal terms, taking seriously the religious dimension of the non-Jewish environment. ${ }^{66}$ The message is: We have a sort of pontifex maximus, too (echein archierea, 8.1), but it is a better one, ${ }^{67}$ it is sworn by god, it is eternal and present ${ }^{68}$ - the son remains the son and will not be replaced by his brother. Such a contemporary reference clearly does not exclude the drawing on the early theologumenon of the son, but questions certain far-reaching explanations on "Hebrews", thinking. ${ }^{69}$ The implication of this rhetoric need not be spelled out:

63. Gelardini 2005a, 123.

64. Paul Ellingworth, The epistle to the Hebrews: a commentary on the Greek text. Michigan 1993, 78; cf. David A. DeSilva, Perseverance in Gratitude: A Socio-Rhetorical Commentary on the Epistle "to the Hebrews". Grand Rapids 2000, $58 \mathrm{f}$.

65. Ellingworth 1993, 79; see also David A. DeSilva, "Exchanging Favor for Wrath: Apostasy in Hebrews and Patron-Client Relationships." Journal of Biblical Literature 115 (1996), 91-116.

66. I thus do not agree to DeSilva's stress on shame: David A. DeSilva, "Despising Shame: A Cultural-Anthropological Investigation of the Epistle to the Hebrews." Journal of Biblical Literature 113 (1994), 439-461; id. 2000.

67. Cf. Gräßer 1993, 79.

68. See Ernst Käsemann, Das wandernde Gottesvolk. Eine Untersuchung zum Hebräerbrief. Göttingen 1957, 72.

69. As John Dunnill, Covenant and sacrifice in the Letter to the Hebrews. Cambridge 1992, 188-226. To the contrary, Jon M. Isaak, Situating the Letter to the Hebrews in Early Christian History. Studies in the Bible and Early Christianity 53. Lewiston 2002, 55-61 questions the possibility of an argument from a context reconstructed out of the text. 
Sacrificial cult monopolized in heaven renders earthly sacrifice superfluous. This is cult criticism in cultic language. ${ }^{70}$

For Roman historians my reading of "Hebrews" would be a welcome document for the non-senatorial view of Domitian's reign, for classical philologists an interesting parallel to Pliny's rhetorical strategy in his panegyric on Trajan. For a historian of religion it is an instance of the intensive interaction and open boundaries in the complex religious ecology of the Roman Empire. ${ }^{71}$ After all, even sacrifice in the beyond is a kind of sacrifice.

Research group „Religious Individualisation in historical perspective“ Max Weber Centre of the University of Erfurt

Am Hügel 1

D-99084 Erfurt

Joerg.ruepke@uni-erfurt.de

70. Patrick Gray, The Epistle to the Hebrews and Greco-Roman Critiques of Superstition. Leiden 2004, 221; sim. Albert Vanhoye, Structure and message on the Epistle to the Hebrews. Studia biblica 12. Rom 1989, 16; Marie E. Isaacs, "Priesthood and the Epistle to the Hebrews." Heythrop Journal 38 (1997), 51-62, esp. 56.

71. See Jörg Rüpke, "Early Christianity in, and out of, context", Journal of Roman Studies 99 (2009), 182-193, esp. 191-2 and id. "Religiöser Pluralismus und das römische Reich", Hubert Cancik, Jörg Rüpke (edd.), Die Religion des Imperium Romanum: Koine und Konfrontationen. Tübingen: Mohr Siebeck, 2009, 350-1; for the problematic notion of 'cult' see Michel Malaise, Pour une terminologie et une analyse des cultes isiaques. Mémoire de la Classe des Lettres 3,35. Bruxelles 2005, 201-220. 


\section{REFERENCES}

Abramenko, Andrik, 1994. "Zeitkritik bei Sueton: Zur Datierung der Vitae Caesarum.” Hermes 122 (1994), 80-94.

Aitken, Ellen Bradshaw, 2005. "Portraying the Temple in Stone and Text: The Arch of Titus and the Epistle to the Hebrews." In: Gelardini 2005. 131-148.

Arata, Francesco Paolo, 1997. “Un 'sacellum' d'età imperiale all'interno del Museo Capitolino.” BCAR 98 (1997), 129-162.

Attridge, Harold W., 1989. The Epistle to the Hebrews. A Commentary. Philadelphia: Fortress Press, 1989.

Bonnet, Corinne; RÜPKe, Jörg; ScarpI, Paolo (edd.), 2006, Religions orientales - culti misterici: Neue Perspektiven - nouvelle perspectives prospettive nuove (Potsdamer altertumswissenschaftliche Beiträge 16), Stuttgart: Steiner, 2006.

Bonnet, Corinne; RüPKE, Jörg (edd.), 2009, Les religions orientales dans les mondes grec et romain = Die orientalischen Religionen in der griechischen und römischen Welt = Trivium: Revue franco-allemande de sciences humaines et sociales/Deutsch-französische Zeitschrift für Geistes- und Sozialwissenschaften 4, Paris: Maison des sciences de l'homme, 2009 [http://trivium.revues.org/]

Boyle, A. J., 2003. "Introduction: Reading Flavian Rome.” In: Boyle, A.J.; J. W. Dominik (edd.), Flavian Rome: Culture, Image, Text. Leiden: Brill, 2003. 1-68.

BrucE, Frederick Fyvie (ed.), 1990. The Epistle to the Hebrews. Revised Edition. Michigan: Grand Rapids, 1990.

CANCIK, Hubert, 1990. "Größe und Kolossalität als religiöse und aesthetische Kategorien: Versuch einer Begriffsbestimmung am Beispiel von Statius, Silve I 1: Ecus maximus Domitiani imperatoris." Visible Religion 7 (1990), 51-68; repr. id., Verse und Sachen: Kulturwissenschaftliche Interpretationen römischer Dichtung, éd. Richard Faber, Barbara von Reibnitz, Würzburg: Königshausen \& Neumann, 2003, 224-248.

CAndiLIo, Daniela, 1991. "Indagini archeologiche nell' aula ottagona delle Terme di Diocleziano." NS 1/2 1 (1990/91), 165-183.

Clauss, Manfred, 1999. Kaiser und Gott: Herrscherkult im römischen Reich. Stuttgart: Teubner, 1999.

Coleman, K., 1987. "The Emperor Domitian and Literature." Aufstieg und Niedergang der römischen Welt II.32,5 (1987), 3087-3115.

DESILVA, David A., 1994. "Despising Shame: A Cultural-Anthropological Investigation of the Epistle to the Hebrews." Journal of Biblical Literature 113 (1994), 439-461. 
- 1996. "Exchanging Favor for Wrath: Apostasy in Hebrews and PatronClient Relationships.” Journal of Biblical Literature 115 (1996), 91116.

- 2000. Perseverance in Gratitude: A Socio-Rhetorical Commentary on the Epistle "to the Hebrews". Grand Rapids: Eerdmans, 2000.

DunNILL, John, 1992. Covenant and sacrifice in the Letter to the Hebrews. Cambridge: University Press, 1992.

EllingWORTH, Paul, 1993. The epistle to the Hebrews: a commentary on the Greek text. Michigan: Grand Rapids, 1993.

FISHWICK, Duncan, 1987. The imperial cult in the Latin west: Studies in the ruler cult of the western provinces of the Roman Empire. I: 1-2. EPRO 108. Leiden: Brill, 1987.

FREDRICK, David, 2003. "Architecture and Surveillance in Flavian Rome." In: Boyle, A.J.; J. W. Dominik (edd.), Flavian Rome: Culture, Image, Text. Leiden: Brill, 2003. 199-227.

Gelardini, Gabriella (ed.), 2005. Hebrews: Contemporary Methods new Insights. Biblical Interpretations Series 75. Leiden: Brill, 2005.

Gelardini, Gabriella, 2005a. "Hebrews, an Ancient Synagogue Homily for Tisha be-Av: Its Function, its Basis, its Theological Interpretation." in: Gelardini 2005. 107-127.

GIRARD, Jean-Louis, 1981. "Domitien et Minerve: une prédilection impériale.” Aufstieg und Niedergang der Römischen Welt II.17,1 (1981), 233-245.

Gordon, Richard, 1990. "The Veil of Power: emperors, sacrificers and benefactors." Beard, Mary; North, John (edd.), Pagan Priests: Religion and Power in the Ancient World. London: Duckworth, 1990. 201-231.

GrässEr, Erich, 1990. An die Hebräer. In: Brox, Norbert u.a. (Hg.): Evangelisch-katholischer Kommentar zum Neuen Testament, Bd. XVII/ 1. Zürich/Braunschweig/Neukirchen: Benziger 1990.

- 1993. An die Hebräer. In Brox, Norbert u.a. (Hg.): Evangelischkatholischer Kommentar zum Neuen Testament, Bd. XVII/ 2. Zürich/ Braunschweig/Neukirchen: Benziger, 1993.

Gray, Patrick 2003. "Brotherly Love and the High Priest Christology of Hebrews.” Journal of Biblical Literature 122 (2003), 335-351.

- 2004. The Epistle to the Hebrews and Greco-Roman Critiques of Superstition. Leiden: Brill, 2004.

Hagner, Donald A., 2002. Encountering the Book of Hebrews: An Exposition. Grand Rapids: Baker, 2002. Repr. 2004.

Hardie A., 1983. Statius and the Silvae. Poets, patrons and epideixis in the Graeco-Roman world. Liverpool: Cairns, 1983. 
Hughes, Philip Edgcumbe, 1977. A commentary on the Epistle to the Hebrews. Michigan: Grand Rapids, 1977.

Hurst, Lincoln Douglas, 1990. The Epistle to the Hebrews: is background and thought. Cambridge: University Press, 1990.

IsAacs, Marie E., 1997 "Priesthood and the Epistle to the Hebrews." Heythrop Journal 38 (1997), 51-62.

IsAAK, Jon M., 2002. Situating the Letter to the Hebrews in Early Christian History. Studies in the Bible and Early Christianity 53. Lewiston: Mellen Press, 2002.

Jones, Brian W., 1992. The Emperor Domitian. London: Routledge, 1992.

KAntiRÉA, Maria, 2007. Les dieux et les dieux Augustes: Le culte impérial en Grèce sous les Julio-claudiens et les Flaviens. Etudes épigraphiques et archéologiques. Meletemata 50. Athenes: de Boccard, 2007.

KäSEManN, Ernst, 1957. Das wandernde Gottesvolk. Eine Untersuchung zum Hebräerbrief. Göttingen: Vandenhoeck, 1957.

Koester, Craig R., 2001. Hebrews: a new translation with introduction and commentary, in: The Anchor Bible, Bd. 36. New York: Random House, 2001.

Leberl, Jens, 1997. Domitian und die Dichter: Poesie als Medium der Herrschaftsdarstellung.Hypomnemata 154. Göttingen: Vandenhoeck \& Ruprecht, 2004.

Levene, D. S., 1997. "God and Man in the Classical Latin Panegyric." Proceedings of the Cambridge Philological Society 43 (1997), 66-103.

Lincoln, Andrew, 2006. Hebrews: A Guide. London/New York: T\&T Clark, 2006.

LOADER, William R.G., 1981. Sohn und Hohepriester: eine traditionsgeschichtliche Untersuchung zur Christologie des Hebräerbriefes. Wissenschaftliche Monographien zum Alten und Neuen Testament, Bd. 53. Neukirchen-Vluyn: Neukirchener Verlag des Erziehungsvereins, 1981.

LöHR, Hermut, 2005. "Reflections of Rhetorical Terminology in Hebrews." In: Gelardini 2005. 199-210.

Malaise, Michel, 2005. Pour une terminologie et une analyse des cultes isiaques. Mémoire de la Classe des Lettres 3,35. Bruxelles: Académie royale de Belgique, 2005.

Martin, Alain, 1987. La titulature épigraphique de Domitien. Beiträge zur klassischen Philologie 181. Frankfurt am Main: Athenäum, 1987.

Mason, Eric Farrel, 2008. "You Are a Priest forever": second Temple Jewish Messianism and the Priestly Christology of the Epistle to the Hebrews. Leiden: Brill, 2008. 
Molthagen, Joachim, 1995. "Die Lage der Christen im römischen Reich nach dem 1. Petrusbrief: Zum Problem einer domitianischen Verfolgung." Historia 44 (1995), 422-458.

Nauta, Ruurd R., 2002. Poetry for Patrons: Literary Communication in the Age of Domitian. Mnemosyne suppl. 206. Leiden: Brill, 2002.

Nissilae, Keijo, 1979. Das Hohepriestermotiv im Hebräerbrief - eine exegetische Untersuchung. Schriften der Finnischen Exegetischen Gesellschaft 33. Helsinki: Exegetische Gesellschaft, 1979.

RIEMER, Ulrike, 1998. Das Tier auf dem Kaiserthron? Eine Untersuchung zur Offenbarung des Johannes als historischer Quelle. Beiträge zur Altertumskunde 114. Stuttgart: Teubner, 1998.

Rissi, Matthias, 1987. Die Theologie des Hebräerbriefs: Ihre Verankerung in der Situation des Verfassers und seiner Leser. Wissenschaftliche Untersuchungen zum Neuen Testament 41. Tübingen: Mohr Siebeck, 1987.

Rosso, Emmanuelle, 2006. "La diffusion de l'idéologie flavienne dans les provinces occidentales de l'Empire: le décor sculpté des monuments publics", in: M. Navarro Caballero and J.-M. Roddaz (eds.), La transmission de l'idéologie impériale dans l'Occident romain. Ausonius Études 13. Bordeaux: Ausonius, 2006. 247-271.

RÜPKE, Jörg, 2005. Fasti sacerdotum: Die Mitglieder der Priesterschaften und das sakrale Funktionspersonal römischer, griechischer, orientalischer und jüdisch-christlicher Kulte in der Stadt Rom von 300 v. Chr. bis 499 n. Chr. Potsdamer altertumswissenschaftliche Beiträge 12/1-3. Stuttgart: Steiner, 2005.

- 2008 Fasti sacerdotum: A Prosopography of Pagan, Jewish, and Christian Religious Officials in the City of Rome, 300 BC to AD 499. Biographies of Christian Officials by Anne Glock. Trsl. by David Richardson. Oxford: Oxford University Press, 2008.

- 2009 "Early Christianity in, and out of, context", Journal of Roman Studies 99 (2009), 182-193.

- 2009 (a). "Religiöser Pluralismus und das römische Reich. " Cancik, Hubert; Rüpke, Jörg (edd.), Die Religion des Imperium Romanum: Koine und Konfrontationen. Tübingen: Mohr Siebeck, 2009. 331-354.

SAUter, Franz, 1934. Der römische Kaiserkult bei Martial und Statius. Tübinger Beiträge zur Altertumswissenschaft 21 Stuttgart: Kolhammer, 1934.

Scholer, John M., 1991. Proleptic Priests. Priesthood in the Epistle to the Hebrews. Journal for the Study of the New Testament Supplement Series 49. Sheffield: Academic Press, 1991.

SCHUMACHER,Leonhard, 1978. "Die vierhohen römischen Priesterkollegien unter den Flaviern, den Antoninen und den Severern (69-235 n. Chr.)." Aufstieg und Niedergang der Römischen Welt II.16,1 (1978), 655-819. 
ScotT, Kenneth, 1936. The Imperial Cult Under the Flavians. [Repr. New York: Arno Press] Stuttgart: Kohlhammer, 1936.

STEPPER, Ruth, 2003. "Der Kaiser als Priester: Schwerpunkte und Reichweite seines oberpontifikalen Handelns.” Cancik, Hubert; Hitzl, Konrad (Hgg.), Die Praxis der Herrscherverehrung in Rom und seinen Provinzen. Tübingen: Mohr Siebeck, 2003. 157-187.

- 2003a Augustus et sacerdos: Untersuchungen zum römischen Kaiser als Priester. Potsdamer altertumswissenschaftliche Beiträge 9. Stuttgart: Steiner, 2003 (a).

STEWART, Roberta, 1994. "Domitian and Roman Religion: Juvenal, Satires Two and Four." TAPhA 124 (1994), 309-330.

Strobel, August, 1975. Der Brief an die Hebräer. Das Neue Testament Deutsch 9/2. 4. überarb. Aufl. (1975). Göttingen: Vandenhoeck und Ruprecht 1991.

Stroumsa, Guy, 1999. Barbarian Philosophy: The Religious Revolution of Early Christianity. WUNT 112. Tübingen: Mohr Siebeck, 1999.

- 2005. La fin du sacrifice. Les mutations religieuses de l'Antiquité tardive. Collection Collège de France. Paris: Odile Jacob, 2005.

URNER, Christiana, 1993. Kaiser Domitian im Urteil antiker literarischer Quellen und moderner Forschung. Diss. Augsburg 1993.

VAN HAEPEREN, Françoise, 2002. Le collège pontifical ( $3^{e}$ s. a. C. $-4^{e}$ s. p. C.): contribution à l'étude de la religion publique romaine. Bruxelles: Institut historique belge de Rome, 2002.

Vanhoye, Albert, 1989. Structure and message on the Epistle to the Hebrews. Studia biblica 12. Rom: Editrice Pontificio Instituto Biblico, 1989. 